\title{
In vitro pre-vascularisation of tissue-engineered constructs A co-culture perspective
}

\author{
Vascular Cell 6:13 I DOI: 10.1186/2045-824X-6-13 | C C Li et al.; licensee Publiverse Online \\ S.R.L. 2014 \\ Received: 16 Feb 2014 | Accepted: 12 Feb 2014 | Published: 21 Feb 2014 \\ Baldwin Jeremy, Antille Mélanie, Bonda Ulrich, De-Juan-Pardo Elena M, \\ Khosrotehrani Kiarash, Ivanovski Saso, Petcu Eugen Bogdan, Hutmacher Dietmar Werner ${ }^{@}$ \\ ${ }^{+}$Contributed equally ${ }^{\circledR}$ Corresponding author
}

\section{Abstract}

In vitro pre-vascularization is one of the main vascularization strategies in the tissue engineering field. Culturing cells within a tissue-engineered construct (TEC) prior to implantation provides researchers with a greater degree of control over the fate of the cells. However, balancing the diverse range of different cell culture parameters in vitro is seldom easy and in most cases, especially in highly vascularized tissues, more than one cell type will reside within the cell culture system. Culturing multiple cell types in the same construct presents its own unique challenges and pitfalls. The following review examines endothelial-driven vascularization and evaluates the direct and indirect role other cell types have in vessel and capillary formation. The article then analyses the different parameters researchers can modulate in a co-culture system in order to design optimal tissue-engineered constructs to match desired clinical applications.

\section{Keywords}

Co-culture - Vascularisation - Tissue engineering - Matrices

\section{Introduction}

Researchers have two main options when vascularizing tissue-engineered constructs: either implant the construct in vivo whereby the host system and local microenvironment largely guide vascularization and the organization of cells, or culture the cells under controlled conditions in order to develop a functioning vascular network in vitro before implantation [ 1,2]. The latter strategy offers a higher degree of control, as researchers are able to modulate and optimize parameters under controlled conditions prior to implantation. In in vitro culture systems capillaries and vessels are formed de novo (vasculogenesis) rather than from existing vasculature (angiogenesis). In most tissue engineering constructs capillaries and vessels are formed by endothelial or endothelial progenitor cells (EPC) rather than by precursor cells, such as angioblasts, as described in the traditional definition of vasculogenesis. Moreover, in a majority of cases, other non-endothelial cells will also be cultured within the same tissue engineered construct depending on the tissue of interest [3]. Endothelial cells are a key structural and functional component of blood vessels and capillaries, and play a critical role in the revascularization of local site defects in wound healing and repair, such as diabetic ulcers, damaged cardiac tissue and bone regeneration [ 4-7]. Numerous studies have shown that the addition of endothelial cells to tissue-engineered constructs increases vascularization and perfusion in both in vitro and in vivo settings [ 8-11]. However, managing multiple cell types in the same system can be 
difficult. What may be an optimal condition for one cell type may be detrimental or lethal to another cell type. Researchers need to find the right balance for each cell type, whilst taking into consideration the intended structural and functional purpose of the tissue-engineered construct. The following article reviews the various parameters to consider in an in vitro co-culture system with a particular focus on vascularization.

\section{Cell source}

A key first decision in designing an in vitro co-culture system is the selection of appropriate cell types.

\section{Endothelial and precursor cells}

Endothelial cells are present in most tissues within the human body; however, their relative abundance and composition varies from tissue to tissue [12]. A microarray study on the expression profiles of 53 endothelial cells showed distinct tissue-specific expression patterns in cells isolated from different blood vessels and microvasculature in the body [13]. There are a wide variety of different types of endothelial cells used in the literature. Researchers seeking to model a particular biological system or disease state may choose to isolate them directly from the tissue of interest. The logic behind isolating cells from the tissue of interest is that the researchers will be able to isolate endothelial subpopulations specific to the microenvironment that they wish to recapitulate. However, from a tissue engineering perspective, isolating tissue-specific endothelial cells may not be a feasible strategy as retrieving these cells may require an invasive procedure, and in the case of major organs or tissues may not be a viable option. In order for a specific cell-based tissue engineering approach to be practical in a clinical setting, the source of cells needs to be (i) relatively abundant, (ii) readily available and (iii) pose a minimal to low risk to patient/donors. Examples of non-invasive cell sources include placental or umbilical cords which are commonly discarded as medical waste, and examples of minimally invasive procedures for isolation of endothelial cells include peripheral blood and skin biopsy [ 14-16]. It is important to remember that isolated primary cells are heterogeneous and contain a mix of different endothelial cell subpopulations. In 2004 Ingram et al. identified a novel cell hierarchy among endothelial cells found in human peripheral and umbilical cord blood based on clonogenic and proliferative potential [ 17]. The endothelial lineage is believed to follow a similar hierarchical as myeloid and lymphoid lineages in which a primitive stem cell gives rise to proliferating progenitor cells, followed by the progression to terminally differentiated cells [17]. Figure 1 shows the model of endothelial cell hierarchy based on proliferative and clonogenic potential, thus defining endothelial progenitors (EPC) as cells giving rise to high proliferative colonies with the capacity to form blood vessels upon transplantation. A further study identified a subpopulation of endothelial progenitor cells (EPC) within human umbilical vein endothelial cells (HUVEC) and human aortic endothelial cells (HAEC) [ 18]. Both HUVEC and HAEC can be isolated from vessel walls and were previously thought to consist of only mature differentiated endothelial cells [19]. The heterogeneous composition of isolated endothelial cells may affect the reproducibility of cell-based treatments and isolated cells may need to be sorted into individual cell populations.

\section{Figure 1}

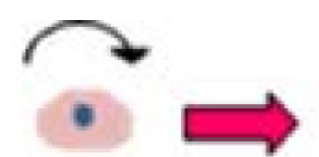

HPP-ECFC
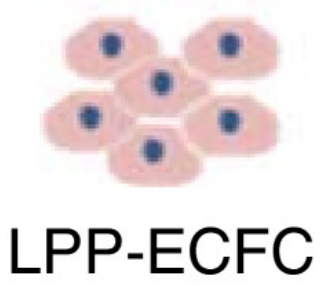

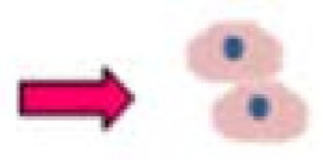

Endothelial cell cluster
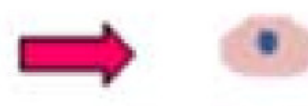

\section{Mature Endothelial cells}

Overview of endothelial cell hierarchy.High proliferative potential- endothelial colony forming cells (HPP-ECFC) give rise to all other subsequent endothelial progenitor cells, can achieve greater than 100 population doublings and can form secondary and tertiary colonies upon replating. Low proliferative potential -endothelial colony forming cells (LPP-ECFC) can give rise to colonies 
containing more than 50 cells, whilst endothelial cell clusters give rise to colonies with fewer than 50 cells. Neither LPP-ECFC or endothelial clusters can give rise to secondary or tertiary colonies. Mature endothelial cells are terminally differentiated and have a limited proliferative potential [ 17].

The therapeutic potential of EPC subpopulations of endothelial cells has garnered a significant amount of interest within the research community in recent years. EPCs have been shown to have enhanced proliferative potential, are able to differentiate and give rise to all subsets of the endothelial cell lineage and have been shown to improve vasculogenic activity [20]. Other studies have also shown that EPC have a higher survival rate in vitro in comparison to HUVEC [21]. Despite these facts, researchers have experienced mixed and sometimes conflicting results when trying to translate EPCs in a preclinical and clinical setting [22]. A potential source of this discrepancy may lie in the lack of a unified definition of an EPC and an understanding of mechanisms that underline the cells therapeutic mode of action. Much of the controversy stems from the diverse range of cell isolation techniques and cell markers that have been historically used to identify and characterize EPCs [ 23]. The three main types of EPCs in literature, as classified by their isolation from peripheral blood - mononuclear cells (PB-MNC), include culture of colony forming unit Hill (CFU)-Hill cells, circulating angiogenic cells (CAC) and endothelial colony forming cells (ECFC) [ 24- 26].

CFU-Hill are non-adherent PB-MNC that give rise to colonies after 5 days following depletion of adherent cells on fibronectin and CAC cells are adherent PB-MNC that attach to fibronectin or gelatin surface after 4-6 days of culture [ 24, 25]. Both CFU-Hill and CAC cells co-express CD31, VEGFR-2 and CD133 [ 27]. CD133 is a hematopoietic stem cell (HSC) marker that is lost as cell differentiate [ 28]. Peichev et al. hypothesized that CD133 may also be a marker for immature EPC populations [ 29]. A later study by Case et al. in 2007 however showed that $99 \%$ of CD34+ VEGFR-2+ CD133+ cells also co-expressed CD45+, a common leukocyte antigen, not expressed by endothelial cells [ 30]. In addition CD34+ VEGFR-2+ CD133+ cells also readily ingest bacteria and lacked the ability to form human vessels de novo in vivo [ 22]. Hirschi et al. proposed that the isolation strategies for CFUHill and CAC cells may actually enrich for monocyte/macrophage committed cells rather than EPCs, but that these cell types can mimic an endothelial phenotype under angiogenic conditions [27]. These findings raises important technical issues, as these cells retain macrophage/monocyte phenotype and do not full commit to endothelial cell fate, if for example the angiogenic stimulus is removed or the cells are presented with an inflammatory or foreign body response, common at surgical/injury sites, will the cells revert to their previous macrophage state [27].

ECFC on the other hand are late outgrowth cells that form colonies on type 1 rat tail collagen following 14-21 days of culture [ 26]. According to Ingram et al. ECFC more closely match the criteria of being a true EPC [ 17]. Unlike CFU-Hill and CAC cells, ECFCs do not express haemopoetic markers such as CD133 and CD45 [ 31]. ECFC are highly proliferative and have the potential to form both secondary and tertiary colonies on replating [17]. ECFC are also capable of forming human vessels de novo in vivo and incorporating into existing vascular networks created by the co-culture of mature endothelial and fibroblast cells [32].

The findings from these studies highlight the striking differences between the different classes of putative EPCs and have important implication for their therapeutic application. Although CD34+ VEGFR-2+ CD133+ cells cannot initiate vessel formation de novo in vivo, the cells can still contribute to neoangiogenesis. For example, the putative EPCs, in contrast to late outgrowth ECFCs, are able to support existing vasculature through the secretion of angiogenic factors [ 32]. CD34+ VEGFR-2+ CD133+ cells can hone to and transiently adhere to vasculature surfaces that lack an endothelial lining [ 27,29]. The endothelial covering is critical in normal blood vessel and capillary function. The ability of the putative EPCs to mimic endothelial phenotype suggests the cells support damaged or developing vessels by providing a temporary substitute endothelium until it can be replaced by endothelial cells [27]. Further research is needed to fully characterize each EPC cell type and their mode of action in order to develop more targeted strategies for each cell type in tissue engineering.

Another major limitation of ECFCs is their rarity within the human body. EPC only make up $0.01 \%$ of circulating mononuclear cells in peripheral blood [ 33]. An alternative source of ECFC is umbilical cord blood or placental tissue. The number of endothelial cell colonies derived from umbilical cord blood was 15 times higher than from equivalent volumes $(20 \mathrm{~mL})$ of peripheral blood [ 17]. The colonies formed by umbilical cord blood were also consistently larger than those isolated from peripheral blood [ 17]. More recently, it has now become possible to also isolate ECFCs from the placenta tissue. From a single placenta $(500-600 \mathrm{~g})$ it is possible to isolated the same amount of 
ECFCs as found in 27 whole cord blood $(60 \mathrm{~mL})$ samples [ 34]. Gene expression and functional studies have demonstrated that these cells are equivalent to umbilical cord blood derived ECFCs [ 34]. The high number of ECFCs that can be derived from these tissues, that are commonly discarded, is opening new possibilities in tissue engineering, in particular in large defect applications that require high cell numbers.

An alternative strategy may be to expand isolated ECFC ex vivo, however only a limited number of studies have explored the effects that ongoing cell culture may have on ECFCs. Endothelial progenitor cells at a single cell level can be expanded 10,000-fold and from a single cord blood sample it is possible to obtain greater than $10^{9}$ progeny $[17,18]$. However these expanded cells may not necessarily all be progenitor cells. A common problem with ex vivo expansion of progenitor cells is that mature cells rather than immature cells are expanded [35]. Therefore ECFC cells in culture may develop into a mixed population of endothelial cells. A study by Corselli et al. also observed a progressive differentiation of ECFC into more mature endothelial cells over time in culture based on decrease in proliferative potential, reduction of CD34 expression and improved tube formation capacity [36]. Moreover, the same study found that large scale ex vivo expansion of endothelial progenitor cells can also result in a high incidence of cytogenetic alteration [36]. Interestingly, this phenomena was only observed in umbilical cord derived EPCs, but not in blood-derived EPCs. Although no tumorgenicity was observed by the cells in vivo, it does raise important health and safety concerns for use of expanded endothelial progenitor cells in clinical applications. Further research is required to determine the optimal conditions to effectively expand ECFC whilst conserving progenitor expression and phenotype.

Mature endothelial cells and endothelial cell clusters lack the ability to be expanded out into high numbers like their ECFC counterparts, however these endothelial cells are still capable of forming capillary-like structures. ECFC cells are responsive to angiogenic factors, have a high survival rate and are believed to play a key role in maintaining vessel wall integrity [ 18,19$]$. Therefore the use of mature endothelial cells/endothelial cluster subpopulations to form an in vitro capillary network without progenitor endothelial cells, such as ECFCs, potentially draws into question the long-term stability of the newly formed vascular network. However this issue may be overcome later after implantation when the vascular network is integrated and reperfused by the host system, which may allow the construct to be repopulated by circulating ECFCs in adult peripheral blood.

\section{Multipotent adult stem cells}

Adult stem cells are multipotent cells that are capable of differentiating into a narrow range of different cell types [ 37]. Recent advances in our understanding of stem cell biology and regulation have provided researchers with a range of novel tools and research strategies to guide cell fate both within and outside their traditional cell lineages. Bone marrow mesenchymal stem cells (BM-MSC) have been shown to readily differentiate into endothelial cells under angiogenic conditions.

Differentiated BM-MSC express several endothelial markers in vitro including, vWF, VEGFR1/2

(FLT-1/KDR) and VE-cadherin [ 38]. BM-MSC formed vessels in vivo which were fully perfused as demonstrated by the presence of erythrocytes in the vessel lumen [39]. Adipose derived stem cells are also capable of differentiating into endothelial cells following stiumulus by VEGF and FGF-2 [ 40]. These cells are positive for CD31, CD34, VE-cadherin and endothelial cell nitric oxide synthase (eNOS). The cells are also capable of forming cord-like structures in vitro on matrigel, and when injected into an ischemic hindlimb mouse model formed vessels within the mouse vasculature and markedly improved blood flow within the ischemic hindlinmb. It is also possible now to isolate multipotent stem cells from urine. Urine-derived stem cells (USC) are isolated from voided urine or urine from the upper urinary tract [ 41]. USCs have high proliferative potential and can be expanded up to 50 population doublings [ 42]. USC can be differentiated into endothelial cells following supplementation of VEGF in media. Endothelial differentiated USC have been shown to be capable of forming tubular structures in vitro on matrigel and express several endothelial specific markers, including vWF, CD31, KDR/FLT-1, eNOS and VE-cadherin [ 43]. The advantage of multipotent adult stem cells from a tissue engineering perspective is that these cell types can be isolated from noninvasive (eg. urine) and minimally invasive (eg. bone marrow; fat tissue) sources. Also unlike induced pluripotent stem cells (iPS) and embryonic stem cells (ESC), they are less likely to form teratomas in vivo .

\section{Pluripotent stem cells}


In the past ten years there has been significant advancement in the fields of stem cell biology and iPS technology [44]. These developments have had a tremendous impact on regenerative medicine and tissue engineering concepts. Unlike endothelial progenitor cells, pluripotent stem cells have the potential of differentiating into all three germ layers [ 45]. The most recognizable and well characterized pluripotent cells are ESCs. A number of studies have been able to differentiate ESC into endothelial and associated mural cells [ 46, 47]. ESC-derived endothelial cells were shown to contribute to the construction of new blood vessels and improved blood flow in a hindlimb ischemia model [ 48]. However ethical concerns surrounding the isolation of ESC limit the widespread application and adoption of this cell technology [ 49]. Other technical limitations associated with the use of ESC include source availability, difficulty in separating out endothelial cells from undifferentiated ESC cell and the potential for ESC to form teratomas [ 49- 51].

iPS cells are differentiated cells that have been genetically reprogrammed to return to a pluripotent stem cell state and therefore circumvent the need to source cells from embryos [ 52]. A large body of research from the mid 1990s to early 2000s identified a number of key genes relating to maintenance and regulation of pluripotency in embryos and ESC [ 53- 58]. In 2006 a seminal paper by Dr Shinya Yamanaka's laboratory at Kyoto University screened 24 of these genes as candidates for inducing pluripotency in somatic cells and identified four factors, including Oct3/4, Sox2, c-Myc and Klf4, that were able to successfully produce iPS cells from mouse adult fibroblast cells [ 59]. Since this study, a number of laboratories have been able to use Dr. Yamanaka's technique to generate iPS cells from a variety of different cell types and species including humans [ 60]. Once the cells have returned to a pluripotent state the cells can then be re-differentiated into endothelial and associated mural cells. Choi et al. were able to differentiate seven human iPS cell lines into endothelial (CD31+, CD34-) cells [61]. The iPS-derived endothelial cells were shown to successfully form capillary-like structures on growth factor reduced matrigel in 2D. Another study by Samuel et al. was able to establish functional blood vessels long-term (280 days) in vivo using endothelial cells and perivascular MSCs from the same human iPS cell line [ 62]. The study was also able to replicate the results using human iPS cells from patients with type 1 diabetes that are predisposed to vascular complications. A particular limitation of iPS cells is that they still may maintain their epigenetic memory (i.e. DNA methylation and histone modification) and prevent the cells from fully recapitulating ESC cells [ 63]. Several of the iPS cell genes are also oncogenes, and like ESCs, these cells are also capable of forming teratomas in vivo [ 64].

Pluripotent stem cells represent a potential universal cell source for endothelial cells, but the technology is still in the early stages of development and if researchers cannot rectify the issues associated with the cells, in particular the safety concerns, the technology will never be able to move beyond pre-clinical applications into clinical regenerative therapies.

\section{Supporting cells}

Cells that are grown in conjunction with endothelial cells can have both a direct and indirect impact on the development of vascular networks in tissue-engineered constructs. Figure 2 highlights the role that these cells can have on capillary formation and maturation.

\section{Figure 2}

\section{(A) Indirect}

\section{(B) Direct}
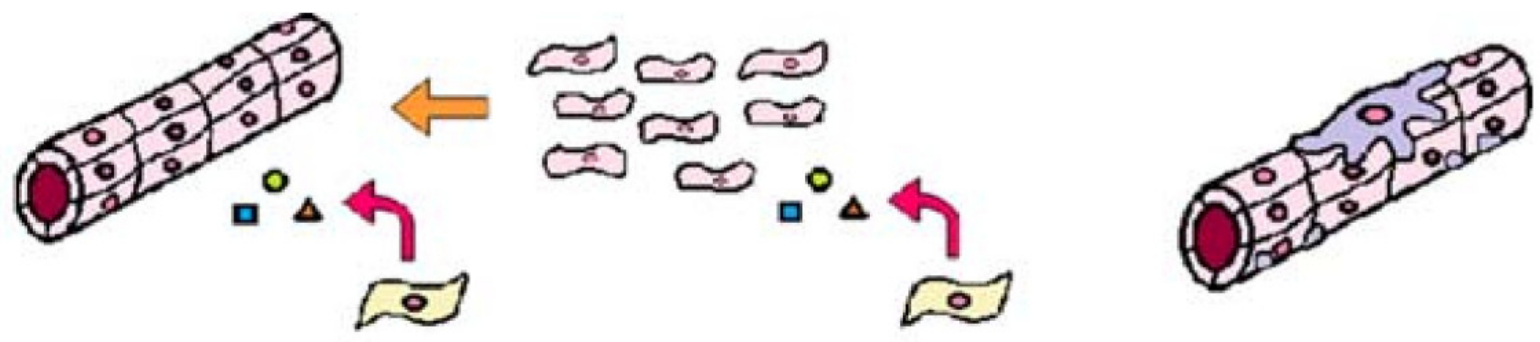

\section{Endothelial Cell}

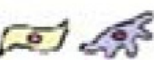

Supporting Cell Type

$\therefore$ Growth Factors/Cytokines

Overview of the roles of supporting cells in capillary formation. (A)Indirect role of supporting 
cells in establishment and maintenance of capillary structures through release of cytokines and growth factors and (B)direct role of supporting cells in the structural and functional support of blood vessels and capillaries.

\section{Assays for the functional assessment of vascularization}

A number of in vitro and in vivo assays are available for assessing capillary formation in tissue engineering constructs. The foremost test for evaluating vascularization in vitro is the formation of capillary structures. In co-culture systems vessel formation can be visualized using endothelial specific-markers, such as CD31 or vWF, or by pre-labeling the cells prior to culture. Capillary structures can be reconstructed in 3D by stitching together single image stills. Skeletonization of networks enables further analysis of morphometric parameters such as vessel volume, branching points, vascular orientation, average segment length and diameter [ 81]. Lumen formation is a critical step in the functionalization and maturation of a capillary networks. Lumen formation can be detected in a variety of different ways. Gel properties can be exploited to directly identify lumens. For example, lumens can be detected in endothelial cells embedded in collagen gels by staining using collagen antibodies. If the inside of the capillary do not stain for collagen, this indicates that a hollow lumen has formed [ 82]. A limitation of this approach is that it is dependent on the availability of antibodies specific to the gel of interest. Lumens can also be indirectly detected by staining for basement membrane deposition and other proteins associated with vacuole formation. Another important marker of vessel functionality is selective permeability. Grainger and Putnam developed a model of inverse permeability in which gels are placed in a solution of fluorescently labelled dextran to allow free diffusion for 30 minutes [ 83]. If the capillaries are mature with competent cell-cell junctions the labeled dextran will not be able to penetrate the inner hollow lumen; if the labeled dextran is detected within the lumen than the tight junctions are incomplete and the capillaries are immature.

Although in vitro assays can assess the vascularization potential of a tissue engineered construct, only in vivo evaluation can demonstrate if capillary structures formed in vitro can survive in a host system and integrate with the host vasculature. In animal models, labeling the cells prior to implantation or in the case of xenograft models the use of species-specific antibodies can be used later during analysis to distinguish between the contributions of donor and host cells in explanted tissue engineered constructs. The detection of erythrocytes in the lumen structures of the vessels following for example a hematoxylin and eosin (H\&E) stain can indicate successful reperfusion via anastomosis with host vasculature. A more concise assay for assessing vessel perfusion in vivo is through the intravenous injection of labeled lectin into the animals prior to sacrifice [ 84]. Lectin binds the endothelium of blood vessels [ 85]. If the vessels have indeed connected to the host circulatory system the labeled lectin can be detected when processing the samples downstream and scanning for the relevant fluorescence. Another assay for evaluating vessel perfusion is through the injection of radio-contrast agents, such as Microfil and Angiofil, prior to sacrifice or post-mortem [ 86, 87]. Similar to the lectin assay, the radio-contrast agent is injected into host vasculature system, but instead of staining the compound polymerizes to form a 3D dimension cast of the circulatory system. Functional vessels in the construct can be visualized in 3D using micro-CT. A disadvantage of this technique is that the radio-contrast agents cannot distinguish between host and donor cells. Advancement in whole mouse imaging systems coupled with cell labeling can assist in tracking cell fate without having to sacrifice the animal [ 88]. This enables real-time monitoring of cells post-implantation and different cell labels can distinguish between multiple cell types. A limitation of this approach is the presence of autofluorescence from innate biological molecules in some tissues, such as skin or fur, which can interfere with labeled cell signals. However, this problem may be overcome using appropriate imaging filters or switching to a bioluminescene encoding protein [ 89].

\section{Co-culture parameters}

There are a number of parameters that require careful consideration when designing a co-culture system. Some conditions may be considered trivial, but can have important implications for the end tissue-engineered product. 
In tissue engineering, scaffolds and matrices provide cells with support and structure to move from 2D tissue culture plate into a 3D microenvironment. The three main types of 3D scaffolds include; solid scaffolds, hydrogels (Figure $3 \mathrm{~A}-\mathrm{B}$ ) or a combination of the two constructs (Figure 3C). Solid scaffolds are porous 3D structures, whilst gels are polymer networks that are expanded throughout their volume by fluid. Thus far, only hydrogels have been shown to form functional vascular networks with lumen in vitro. The main difference between the two constructs is that in hydrogels cells are completely embedded and are able to rearrange themselves in 3D, whilst in scaffolds, despite the fact that the constructs are 3D in nature, the cells are seeded on the scaffold surface and are in this sense on a 2D plane. The complete immersion of cells in a 3D environment is critical in order to allow the cells to self-assemble and organize into functional capillary networks. In 2D endothelial cells can form cord-like structures; however, it is only in 3D that endothelial cells are capable of forming functioning lumens [90]. Lumens are the empty space inside capillaries and vessels in which blood flows, and therefore their development is critical in the effective reperfusion of tissue engineering constructs upon implantation [ 75]. The only exception may be if the cells on the scaffold secrete enough ECM in order to completely encapsulate the endothelial cells.

\section{Figure 3}

(A)

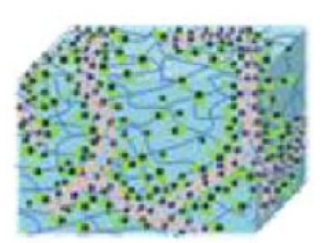

(B)

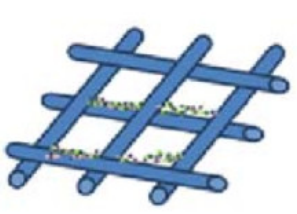

(C)

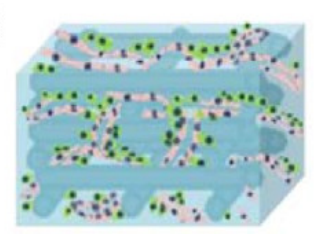

(D)

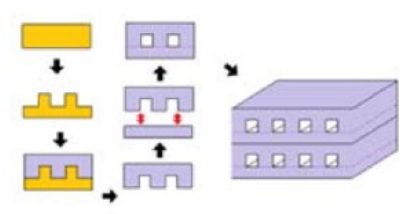

(E)

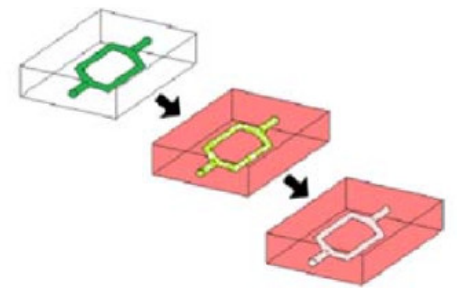

(F)

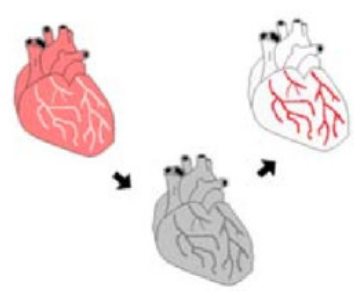

(G)

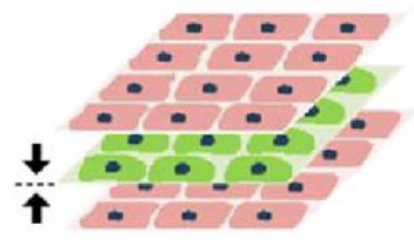

Overview of tissue engineering constructs.Endothelial cells encapsulated within a (A)hydrogel and (B)seeded on a solid scaffold. Only functional capillaries with lumen form in hydrogels. (C)Hybrid construct combining the tube forming capabilities of the hydrogel with the structural support of a scaffold. (D)Photolithography used to etch microchannels into a silicon master mold. Biomaterial cast into mold to create a patterned surface. Patterned layer bonded to flat unpatterned surface to create closed system. Multiple layers can be fused together to create larger 3D constructs.

(E)Biodegradable material dissolves in biomaterial to leave patterned microchannels. (F)Whole tissue organs decellularized leaving the ECM intact with a hollow vasculature network that can later be re-seeded with endothelial cells. (G)Cell sheeting engineering used to create vascularized $3 \mathrm{D}$ constructs by sandwiching endothelial cell sheets with non-endothelial cell sheets together.

However, it is important to note the immersion of cells in a 3D environment by itself also will not lead to capillary formation in vitro, with cells requiring adhesion and degradable sites throughout the matrix in order to move freely and organize themselves into 3D structures [91]. Native ECM derived materials, such as collagen and fibrin gel, naturally have binding and cleavable sites for cells, whereas synthetic gels may require the incorporation of additional peptide sequences, such as RGD (Arg-GlyAsp) binding and matrix metalloproteinase (MMP)-degradable sites [ 91].

The mechanical properties of a construct can also play an important role in capillary formation. In literature the range of stiffness as measured by compression modulus for optimal tube formation in hydrogels varies between different gel types, however in all cases increased vasculature formation was associated with decreasing stiffness [ 92-95]. The phenotypic expression of other cell types on the other hand can increase with increasing stiffness. For example, in bone tissue engineering, stiffer gels can increase bone mineralization and expression of differentiation markers such as osteocalcin, osteopontin and alkaline phosphatase [ 96,97]. The selection of optimal construct stiffness can be problematic if attributes (i.e. vascularisation and bone formation) are desired in the same construct, but inversely related. Researchers need to find a middle ground or alter another parameter in the system. 
A new wave of vascular constructs and designs are helping to speed up the tube formation process and assist with co-culture strategies. The process of capillary formation in vitro follows four main steps (i) cell elongation and cell-cell interaction, (ii) development of nascent endothelial tubular network, (iii) lumen formation and (iv) capillary stabilization and maturation [98]. Cell-driven tubulogenesis and lumen formation involves a complex set of cell-cell interactions and biological mechanisms [ 90]. In latent hydrogels this process can takes time, and produces networks that are often not uniform and can regress after a few days of culture. A new approach researchers are now taking is to pre-fabricate hollow microchannels and to seed endothelial cells within these constructs. This approach helps researchers to skip the initial stages of capillary formation by helping to localize the endothelial cells in these channels and provide a template for network development. Another benefit of this strategy from a co-culture perspective is that it enables researchers to compartmentalize different cell types. For example, endothelial cells can be perfused throughout the channels, whilst other cell types can be seeded in the surrounding biomaterial [ 99]. Microchannels can be fabricated using current microfabrication techniques or be naturally derived by using existing vascular networks and structures from decellularized whole organ and tissues.

Concepts from microfluidics can be utilized to engineer vasculature for tissue engineering. Microfabrication techniques, such as photolithography, can be used to etch micron sized open channels into a silicon master mould (Figure 3D) [ 100]. A polymer of interest can then be poured into the mould in order to create a patterned surface. Once set the patterned layer can be removed and then bonded with a flat unpatterned layer of polymer to create a closed system. Different polymer layers can be fused using plasma treatment, temperature/pressure difference, or other polymer specific properties. These microfluidic constructs can then be further stacked and bonded to create larger 3D tissue engineered constructs. A major limitation of the layer bonding technique is the danger of leaks if the layers are not completely fused together.

Another microfluidic approach is to mould a biodegradable material into the shape of a vasculature network and then embed the construct within a biomaterial of interest (Figure 3E). The construct acts as a sacrificial material that degrades over time to leave hollow microchannels behind. This method can also be combined with additive manufacturing techniques to create complex $3 \mathrm{D}$ vasculature structures [ 101]. Another benefit of biodegradable microfluidic channels is that unlike the layer bonding method the surrounding biomaterial formed is intact and there is a lower danger of leaks forming, however the drawback is that the technique doesn't have the high resolution of other microfabrication techniques such as photolithography.

A final approach is to re-endothelialise decellularized whole tissue or organs using the existing vessel structures as templates (Figure $3 \mathrm{~F}$ ). Advances in decellularization processes in recent years have now made it possible to remove cells from tissue whilst retain the vital structure and bioactivity of the ECM [ 102]. The organs and tissue can also be sourced from xenogenic tissues which are readily available. A limitation of this approach is that users are restricted to the layout of vascular structures in the tissue. There are also still unresolved concerns surrounding the antiginicity, immunogenicity and shelf life of decellularized organs [ 103].

\section{Cell sheet technology}

A final technique for developing tissue engineered constructs is cell sheet technology (Figure $3 \mathrm{G}$ ). Cell sheet engineering is a non-scaffold based approach that uses temperature responsive cell culture surfaces to harvest intact cell sheets that can be stacked together to reconstructs 3D tissue [104]. The temperature responsive culture surfaces are created by treating normal tissue culture plates with poly(N-isoproplyacrylamide)(PIPAAm) that can alternate between states of hydrophobicity and hydrophilicity [ 105]. At temperatures higher than 32 degrees the substrate is hydrophobic and cells can attach to the surface and form a confluent layer. Lowering the temperature below 32 degrees causes the substrate to become hydrophilic and the cells sheet and ECM to detach from the surface. A gel coated plunger can then be used to manipulate and stack the cell sheets. The cell sheet technique has been used to effectively replicate tissue and organs, such as skin and cardiac tissue, both in vitro and in vivo [ 106, 107]. A recent study by Asakawa et al. was able to pre-vascularise a cell sheet construct in vitro by incorporating layers of endothelial cells [ 108]. The formation of tubular structures with hollow lumen was observed in the 3D cell sheet tissue after 7 days. A limitation of this approach is that the cell sheets are fragile and can be difficult to handle [ 109]. Fabrication of cell sheet constructs have also thus far been limited to tissue no thicker than 100-200 $\mu \mathrm{m}$ [ 109].

\section{Cell ratio}


The ratio between the different cell types in co-culture can influence cell characteristics, behavior and survival. In view of the available literature, no consensus exists on the optimal cell ratio of endothelial cells to tissue-specific cells for use in in vitro co-culture studies. The choice of ratio will depend on factors such as cell viability and desired expression of phenotype within the co-culture system. Some groups use a high ratio of endothelial cells as the endothelial cells will not form capillary structures or survive long term at low ratio within the particular systems [ 68, 110]. Others groups favor a higher non-endothelial cell ratio in order to push the tissue engineered construct towards a particular phenotype [ 111, 112]. For example Xing et al. seeded low ratio (1:5 and 1:2) of HUVECs with hOBs to increase osteogenic marker expression [111]. The expression of osteogenic markers, such as alkaline phosphatase and insulin-like growth factor-1 (IGF-1), increased with increasing ratio of osteoblasts, however in all condition the endothelial cells still formed capillary like structures. In a majority of other studies researchers selected only a 1:1 cell ratio, however this may just be for the purposes of simplicity rather than a specific cell benefit $[113,114]$.

A key characteristics to consider when selecting the ratio of cells to use in a co-culture system is the cells individual metabolic and proliferative potential. If the cells proliferative and metabolic activity differs significantly, depending on the duration of in vitro culture the more active cells could overgrow the culture or starve the other cell type, respectively. The best way to optimize the cell ratio is via experimentation. Proliferation studies can easily be conducted in monoculture in 2D or 3D followed by analysis using commercial assays, such as Alamar blue and MTT that measure metabolic activity or CyQuant and PicoGreen that measure DNA content [ 115]. However this approach may not be sufficient because it does not take into account the presence of the other cell type and the effect that it may have on the cells proliferation and activity. A better approach is to perform the proliferative studies in co-culture using various ratios of each cell type. The difficulty in this method is to find a way to distinguish between the cell types. The proliferation assays mentioned previously measure total DNA content or metabolic activity in the system and do not discern between different cell types. This limitation however may be overcome by pre-labeling the cells or staining for cell-specific markers. Labeled cells can be quantified by counting the cells under a microscope or by detaching the cells and processing them via flow cytometry [116]. Flow cytometry and immunostaining can also be used to assess cell expression and maintenance of phenotype at the various cell ratios during ongoing in vitro culture.

\section{Culture medium}

The composition of culture media is one of the key points to consider when culturing cells in vitro . Cell culture medium consists of a complex mixture of amino acids, vitamins, salts, supplements and/or serum that has been individually optimized for each cell type. Common basal medias for endothelial cells include EBM-2, M199, M207 Ham's F12K and MCDB -131. Endothelial cells are also highly dependent on media supplements for proliferation and maintenance of cell morphology and phenotype. A traditional approach to culturing endothelial cell was to supplement the media with endothelial growth cell supplement (ECGS) and heparin [ 117]. ECGS is a crude extract from bovine neural tissue which has been shown to have a potent mitogenic effect on endothelial cells of mammalian origin. The main component of ECGS is FGF which binds with heparin to promote ligand formation with FGFR receptor on endothelial cells to promote cell growth. A limitation of ECGS supplementation is that the product has variable composition and is animal derived. As our knowledge and understanding of endothelial cells has expanded, researchers have developed a greater understanding of the factors important in endothelial growth and development and as a result more chemically defined medias have been developed. Examples of common media supplements include VEGF, EGF, FGF, IGF-1, ascorbic acid, hydrocortisone and SDF-1. However several studies have shown that different endothelial cell types (microvascular vs. macrovascular or mature vs. progenitor endothelial cells) respond differently to various growth factors and cytokines [ 118-122]. Therefore the selection of accompanying supplements is highly dependent on cell source and location.

The use of serum is another important consideration in endothelial cell culture. Serum is a common media additive to support cell growth and viability in vitro, however its composition is undefined and its use to expand cells for tissue engineering application has been linked to immune response in patients and prion transmission [ 123-125]. Several commercially available medias have been developed that substitute serum with increased growth factors and hormones, such as Human endothelial -SFM. These serum free media have been shown to support long-term culture of mature endothelial cells, such as HUAEC, HUVECs and HMVECs, but regardless of the growth factor combination do not support ECFC outgrowth without serum [ 126, 127]. This data suggests that other factors in the serum outside growth factors may play an important role in ECFC expansion. Harvey et 
al. examined the serum factors involved in endothelial cell morphogenesis by depleting lipids from serum with activated charcoal [ 128]. The ability of endothelial cells to form capillaries on matrigel was significantly reduced in media with charcoal-treated serum, however this function was restored following the addition of the lipid sphingosine 1-phosphate. It is hypothesized that the lipids work in synergy with protein growth factors to promote capillary formation and the addition of these factors may improve serum free media strategies. Another alternative strategy is to use human blood products rather than fetal or bovine derived serum. Human blood plasma or platelet lysate have been able to successfully expand ECFC ex vivo [ 127, 129, 130]. Indeed, ECFC cells expanded using humanized cell media maintained their progenitor cell hierarchy, high proliferative potential, endothelial cell markers expression and were capable of forming capillary tubes on matrigel.

In a co-culture scenario each cell will have its own individual media requirements. In some cases the cells may utilise the same media, but often this will not be the case. If cells require different culture media, researchers need to optimize an appropriate media combination that offers acceptable viability, whilst promoting or maintaining desired cell phenotype. Most papers do not explain the decisions that led them to the selection of their chosen media or media combination, despite the critical role that this factor may play in the outcome of the study. The media mixture may depend on the ratio of each cell type used, the sensitivity of cells - one cell type being potentially more sensitive than another to alteration of media composition - and the purpose of the study.

The addition of supplements to media is another issue that has to be considered. Co-culturing cells together will change the expression profile of each cell type through paracrine signaling and cell-cell interactions. The endogenous factors secreted by the cells in the microenvironment may contribute to, or may inhibit, the usual effect of supplements in the medium. For example, Unger et al. showed that in monoculture of HDMEC, exogenous angiogenic factors, such as bFGF or VEGF, were required for microvascular formation [ 68]. However, surprisingly when these components were added to cocultures of HDMEC and osteoblasts, microcapillary formation did not occur. VEGF promotes endothelial cell motility, and in this case too much of this factor may be over stimulating the cells and destabilizing the network.

There may also be a potential significant difference between endothelial capillary formation that is driven by exogenous stimulus in the form of angiogenic supplements added to culture media versus endogenous angiogenic factors secreted by non-endothelial supporter cells in a co-culture system. The exogenous supplements are added as a single dose at the time of media change and their bioactivity will decrease with time depending on the initial concentration, stability of the supplement and relative uptake by the cells. Factors secreted by supporting cells in co-culture are released more steadily over time but as with the exogenous supplements the factors will be removed when the media is changed. Figure 4 shows a visual representation of this phenomenon. It is unclear how the difference between exogenous and endogenous stimulated capillary formation may influences the structural and functional aspects of the networks. In the end, the best way to determine the optimal medium composition may be experimentally by examining not only the proliferation or viability of each cell type but its impact on gene expression and cell phenotype.

Figure 4

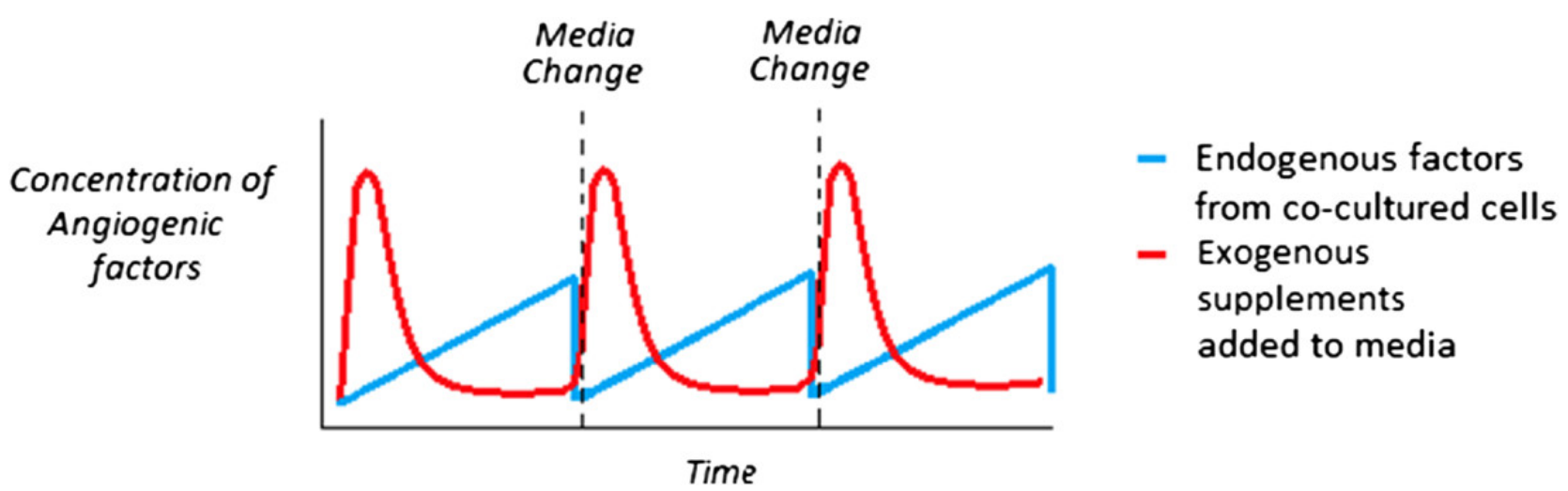

Representation of the difference between angiogenic factors supplied by endogenous support cells in co-culture versus the use of exogenous supplements to media in a static system.Angiogenic factors from an exogenous source (red) are introduced into the system in a spike dependent manner and reduce over time, whilst endogenous angiogenic factors (blue) are released into the system steadily over time. 


\section{Seeding technique}

There are two main types of seeding parameters researchers can modulate: temporal (seed simultaneously or sequentially) and spatial (seed on one construct or multiple constructs).

Seeding the cells in the matrix at the same time allows for a homogeneous mix of cells throughout the construct (Figure 5 A). This is beneficial if cell-cell contact is important for cell function or if the cell types are naturally co-located with one another in the tissue of interest. Researchers can also use the same scaffold, but seed the cells at different times (Figure $5 \mathrm{~B}$ ). In addition to modifying the cell ratio, sequential seeding is beneficial if the cell proliferation rates differ significantly and there is the potential that the more proliferative cell type may take over the construct. Moreover, pre-seeding one cell type in the scaffold may help direct or bias the overall characteristics of the construct towards a particular phenotype or trait of interest. For example, Lyer et al. previously showed that following coculture of EC, fibroblasts and cardiomyocytes in matrigel, the cells formed an organoid that mimicked cardiac structure and function, but the EC cells did not organize into capillary structures [131]. However, a separate study from the same group seeded the EC cells first, followed by fibroblasts 24 hours later, and cardiomyocytes 48 hours later, which resulted in extensive cord formation in the end construct [ 132]. Seeding the EC cells first may have provided the cells with time to form tubes unimpeded and the addition of fibroblasts may have provide the newly formed network with structural support before the addition of the cardiomyocytes. A difficulty associated with sequential seeding in the same construct is the requirement to incorporate cells in a solid scaffold or gel that has already been made. The construct would need to be either porous, include hollow microchannels, or require a chemoattractant to encourage cell ingrowth. In the case of Lyer et al., the organoids were thin microtissue [132].

Figure 5

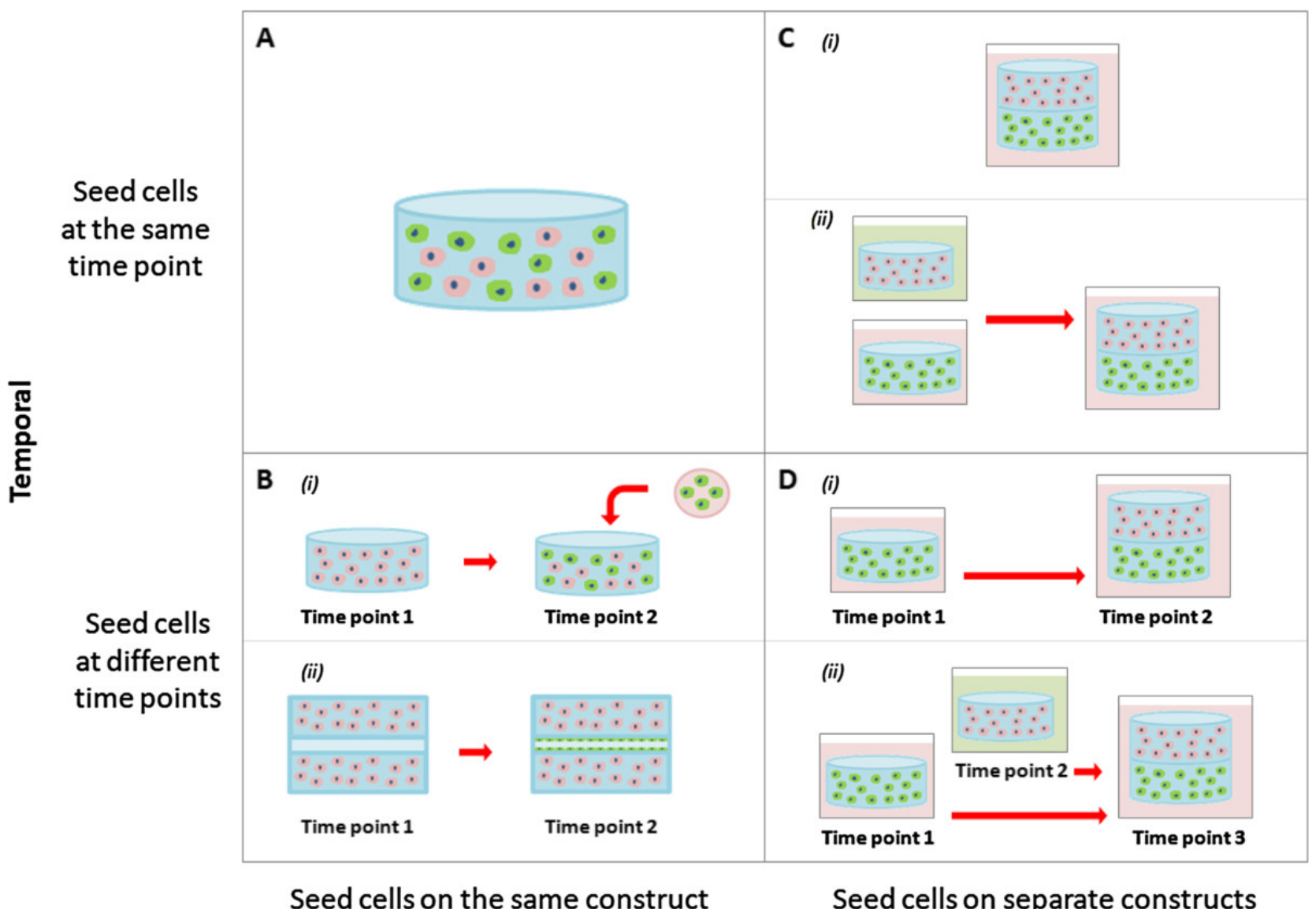

Spatial

Different cell seeding strategies for co-culture systems in tissue engineering. (A)Cells seeded together in the same construct at the same time point. (B)Cells seeded together in the same construct at different time points. (C)Cells seeded in different constructs at the same start point and either cultured (i) together or (ii) separately. (D)Cells seeded in different constructs at different time points and either cultured (i) together or (ii) separately. 
Cells can also be spatially separated on different scaffolds (Figure 5C-D). As previously mentioned, the properties of scaffolds can influence the phenotype of the cells in the tissue-engineered constructs, which may be problematic if competing characteristics are required. A way around this problem is to place the cells in separate scaffolds with optimal properties for each desired cell trait. These scaffolds can be seeded either simultaneously or sequentially but again will depend on the proliferation rates of the cells and the desired cell traits in the construct. An added advantage of spatially separated constructs is that they can also be cultured in different medias before being combined (Figure 5 CiiDii). This can overcome some of the possible problems associated with compromising on shared media conditions. The limitation of spatially separating the cells is that it allows only minimal cell-cell contact between the different cell types.

\section{Dynamic systems}

Bioreactor systems are commonly used within an in vitro cell culture system to control oxygen and nutrient diffusion, alter gene expression and even promote the differentiation of cells. Examples of bioreactor systems for vascularization include hypoxic, rotational and perfusion bioreactors [ 133] . It has been long known that hypoxia can promote angiogenesis and vascularisation in tissue [134]. An oxygen dependent homeostatic mechanism in the body ensures that all cells receive adequate blood supply [ 135]. When tissues are exposed to a low oxygen environment they begin to express factors such as hypoxia-inducible factor 1(HIF-1) which promotes VEGF production [ 135]. The VEGF then acts on the endothelial cells to promote cell migration and vascularisation. Researchers can mimic this cellular response by modulating oxygen tension in a controlled environment such as a incubator to control capillary formation in endothelial cells in vitro [ 136]. In a co-culture setting, hypoxic conditions can have either a positive, negative or no effect on the non-endothelial cells in the culture system. For example, hypoxic conditions have been shown to stimulate MSC differentiation into cartilage and endothelial cells, but actively inhibit MSC differentiation into osteoblasts [ 137-139]. Therefore, hypoxic conditions can have unintended consequences on a co-culture system depending on the end application.

Studies relating to the utilization of rotational bioreactors in co-culture systems have so far shown mixed results. Xing et al. immobilized scaffolds co-cultured with bone marrow stromal cells and endothelial cells on stationary needles in a spinner flask moving in a single direction on the $\mathrm{x}$-axis [ 140]. After a week in the bioreactor, extensive capillary networks formed within the scaffolds. However, in a study by Liu et al. that co-cultured EPC and MSC on immobilized scaffolds using a biaxial bioreactor which was rotating simultaneously on a perpendicular axes ( $\mathrm{X}$ and $\mathrm{Z}$ ), no vessel formation was observed in the dynamic system, but extensive vessel network formed under static conditions after a week of culture in vitro [141]. In this scenario, the bidirectional flow in the biaxial bioreactor may have eliminated the oxygen gradient that occurs naturally in gels and scaffolds and promotes hypoxia-induced VEGF expression, whereas this gradient may be maintained in the static culture and the unidirectional spinner flask.

Perfusion systems can be used to mimic the haemodynamic forces and pressures that occur naturally in the human body. Fluid flow in a bioreactor can be directed through the bulk of a construct, however in most cases it will be directed through hollow microchannels or pores within the construct, similar to those described in section 3.1, that have been pre-seeded with endothelial or perivascular cells. Several studies have shown that mechanical stimulation under peristaltic flow conditions can increase the production of ECM proteins, such as elastin and collagen, and improve the mechanical properties of the vessel or capillary as measured by burst pressure and resistance to shear stress [ 142]. Mechanical stimulation by perfusion systems is critical in pre-conditioning vascular constructs prior to implantation.

\section{Conclusion}

In vitro pre-vascularization strategies provide researchers with greater control over the design and outcome of tissue-engineered constructs. However, with a higher degree of control comes an innumerable range of cell culture options to choose from. In the case of co-culture systems, the amount of choices increases exponentially. Examining the literature, one would not be mistaken in assuming that no consensus exists on optimal cell culture conditions. When reviewing the literature, researchers need to separate out and analyze the different variables in order to make effective 
comparison to their own work or other studies in the literature. This review examined the various important factors to take into consideration when evaluating co-culture systems, such as scaffold type, cell source, cell ratio, medium, seeding technique and bioreactor systems.

There are a variety of cell sources for vascularized tissue constructs; however, endothelial cells are the one cell type that is ubiquitous in almost all systems. EC are heterogeneous in nature and contain a mix of subpopulations. EPC cells hold great promise in the field and have been shown to enhance proliferative ability, survival rate and angiogenic potential. Stem cell-derived EC also represent a viable alternative to directly isolating endothelial cells and its precursors, however issues including ethical concerns, source availability and tumourgenicity limit their application. Other cell types cocultured with endothelial cells have also been shown to play both direct and indirect roles in the development and maturation of capillary networks.The selection of appropriate scaffolds is also an important consideration. ECs require a 3D environment, with adhesion and degradation sites, in order to form functional tube structures with a lumen. EC capillary formation is also strongly associated with decreasing hydrogel stiffness. Modifying cell ratios can help prevent one cell type taking over the construct and/or push a co-culture system towards a particular desired cell trait. When optimizing cell culture media, researchers need to take into account the factors released by both cell types as it changes the dynamics of the culture. Supplements that previously supported a cell type in monoculture may not be required or may even have a detrimental effect on cells in co-culture. Finally, specialized seeding techniques and dynamic bioreactors can be used to overcome barriers in co-culture systems, but the optimal strategy will depend on the desired outcome.Balancing all these conditions can be difficult, and with increasing number of novel biomaterials, cell isolation strategies, media formulations, seeding techniques and bioreactor systems being developed, the variety of options available to researchers is only set to continue. However, it is important for researchers to be able to identify parameters, understand the interrelationship between variables and appreciate the knock-on effect that changing of different conditions can have on a co-culture system, in order to help them appropriately design their experiments and achieve the desired research outcomes.

Additional file 1: Table S1: Summary of various growth factors and cytokines secreted by support cells to promote capillary formation, stabilization and maturation [143-153]. (DOCX $13 \mathrm{~KB})$

\section{Abbreviations}

- $\alpha$-SMA:

Alpha smooth muscle actin

- Ang-1:

Angiopoietin-1

- bFGF:

Basic fibroblast growth factor

- BM-MSC:

Bone marrow mesenchymal stem cells

- CAC:

circulating angiogenic cells

- CFU: colony forming unit

- COX-2:

Cyclooxygenase

- ECFC:

Endothelial colony forming cells

- ECM:

Extracellular matrix

- EPC:

Endothelial progenitor cells

- EC:

Endothelial cells

- ECGS:

Endothelial growth cell supplement 
- eNOS:

Endothelial cell nitric oxide synthase

- ERK:

Extracellular signal regulated kinase

- ESC:

Embryonic stem cells

- HAEC:

Human aortic endothelial cells

- HDMEC:

Human dermal microvascular endothelial cell

- H\&E:

Hematoxylin and eosin

- HSC:

hematopoietic stem cell

- HIF-1:

Hypoxia-inducible factor 1

- HUVEC:

Human umbilical vein endothelial cells

- hbMSC:

Human bone marrow-derived mesenchymal stem cells

- hOB:

Human osteoblast

- HPP-ECFC:

High proliferative potential -endothelial colony forming cells

- IGF-1:

Insulin-like growth factor-1

- iPS:

Induced pluripotent stem cells

- LPP-ECFC:

Low proliferative potential -endothelial colony forming cells

- MMP:

Matrix metalloproteinase

- MSC:

Mesenchymal stem cells

- PB-MNC:

peripheral blood - mononuclear cells

- PIPAAm:

Poly(N-isoproplyacrylamide)

- TIMP-2:

Tissue inhibitor of metalloproteinase 2

- TIMP-3:

Tissue inhibitor of metalloproteinase 3

- UCB:

Umbilical cord blood

- USC:

Urine-derived stem cells

- VEGF:

Vascular Endothelial growth factor

- VEGFR-2:

Vascular Endothelial growth factor receptor-2.

\section{Declarations}

\section{Acknowledgment}

K Khosrotehrani was supported by the NHMRC Australia (project grant 1023368 and fellowship 1023371). 
Below are the links to the authors' original submitted files for images.

Authors' original file for figure 1

Authors' original file for figure 2

Authors' original file for figure 3

Authors' original file for figure 4

Authors' original file for figure 5

Authors' original file for figure 6

\section{Competing interests}

The authors declare that they have no competing interests.

\section{Authors' contribution}

JB, MA, UB, EMD, KK, SI, EP and DWH prepared and wrote the manuscript. All authors read and approved the final manuscript.

\section{References}

1. Rouwkema J, Rivron NC, van Blitterswijk CA. Vascularization in tissue engineering. Trends Biotechnol. 2008;26:434-441.

View Article Google Scholar

2. Ko H, Milthorpe BK, McFarland CD. Engineering thick tissues - the vascularisation problem. Eur Cell Mater. 2007;14:1-18.

View Article Google Scholar

3. Kirkpatrick CJ, Fuchs S, Unger RE. Co-culture systems for vascularization - learning from nature. Adv Drug Deliv Rev. 2011;63:291-299.

View Article Google Scholar

4. Liu Z-J Velazquez OC Hyperoxia, endothelial progenitor cell mobilization, and diabetic wound healing Antioxid Redox Signal 200810186918822638213

$10.1089 /$ ars.2008.2121

5. Sivan-Loukianova E, Awad O, Stepanovic V, Bickenbach J, Schatteman G. CD34+ blood cells accelerate vascularization and healing of diabetic mouse skin wounds. J Vasc Res. 2003;40:368-377.

View Article Google Scholar

6. Shantsila E, Watson T, Lip GY. Endothelial progenitor cells in cardiovascular disorders. J Am Coll Cardiol. 2007;49:741-752.

View Article Google Scholar

7. Matsumoto T, Mifune Y, Kawamoto A, Kuroda R, Shoji T, Iwasaki H, Suzuki T, Oyamada A, Horii M, Yokoyama A. Fracture induced mobilization and incorporation of bone marrowderived endothelial progenitor cells for bone healing. J Cell Physiol. 2008;215:234-242.

View Article Google Scholar

8. Fuchs S, Ghanaati S, Orth C, Barbeck M, Kolbe M, Hofmann A, Eblenkamp M, Gomes M, Reis RL, Kirkpatrick CJ. Contribution of outgrowth endothelial cells from human 
peripheral blood on in vivo vascularization of bone tissue engineered constructs based on starch polycaprolactone scaffolds. Biomaterials. 2009;30:526-534.

View Article Google Scholar

9. Sekine H, Shimizu T, Hobo K, Sekiya S, Yang J, Yamato M, Kurosawa H, Kobayashi E, Okano T. Endothelial cell coculture within tissue-engineered cardiomyocyte sheets enhances neovascularization and improves cardiac function of ischemic hearts. Circulation. 2008;118:S145-S152.

View Article Google Scholar

10. Supp DM Wilson-Landy K Boyce ST Human dermal microvascular endothelial cells form vascular analogs in cultured skin substitutes after grafting to athymic mice FASEB J 2002167978041820617 10.1096/fj.01-0868com

11. Seebach C, Henrich D, Kähling C, Wilhelm K, Tami AE, Alini M, Marzi I. Endothelial progenitor cells and mesenchymal stem cells seeded onto $\beta$-TCP granules enhance early vascularization and bone healing in a critical-sized bone defect in rats. Tissue Eng. 2010;16:1961-1970.

View Article Google Scholar

12. Meyer U, Handschel J, Wiesmann HP. . Fundamentals of Tissue Engineering and Regenerative Medicine. 2009;:-.

View Article Google Scholar

13. Chi J-T Chang HY Haraldsen G Jahnsen FL Troyanskaya OG Chang DS Wang Z Rockson SG van de Rijn M Botstein D Endothelial cell diversity revealed by global expression profiling Proc Natl Acad Sci U S A 20031001062310628196854 10.1073/pnas.1434429100

14. Boyer M, Townsend LE, Vogel LM, Falk J, Reitz-Vick D, Trevor KT, Villalba M, Bendick PJ, Glover JL. Isolation of endothelial cells and their progenitor cells from human peripheral blood. Eur J Vasc Surg. 2000;31:181-189.

View Article Google Scholar

15. Jaffe EA Nachman RL Becker CG Minick CR Culture of human endothelial cells derived from umbilical veins. Identification by morphologic and immunologic criteria $\mathbf{J}$ Clin Invest 197352 2745302542 10.1172/JCI107470

16. Leach L, Bhasin Y, Clark P, Firth J. Isolation of endothelial cells from human term placental villi using immunomagnetic beads. Placenta. 1994;15:355-364.

View Article Google Scholar

17. Ingram DA, Mead LE, Tanaka H, Meade V, Fenoglio A, Mortell K, Pollok K, Ferkowicz MJ, Gilley D, Yoder MC. Identification of a novel hierarchy of endothelial progenitor cells using human peripheral and umbilical cord blood. Blood. 2004;104:2752-2760.

View Article Google Scholar

18. Ingram DA, Mead LE, Moore DB, Woodard W, Fenoglio A, Yoder MC. Vessel wall-derived endothelial cells rapidly proliferate because they contain a complete hierarchy of endothelial progenitor cells. Blood. 2005;105:2783-2786.

View Article Google Scholar

19. Bompais H, Chagraoui J, Canron X, Crisan M, Liu XH, Anjo A, Tolla-Le Port C, Leboeuf M, Charbord P, Bikfalvi A. Human endothelial cells derived from circulating progenitors 
display specific functional properties compared with mature vessel wall endothelial cells. Blood. 2004;103:2577-2584.

View Article Google Scholar

20. Khoo CP, Pozzilli P, Alison MR. Endothelial progenitor cells and their potential therapeutic applications. Regen Med. 2008;3:863-876.

View Article Google Scholar

21. Finkenzeller G, Torio-Padron N, Momeni A, Mehlhorn AT, Stark GB. In vitro angiogenesis properties of endothelial progenitor cells: a promising tool for vascularization of ex vivo engineered tissues. Tissue Eng. 2007;13:1413-1420.

View Article Google Scholar

22. Yoder MC Mead LE Prater D Krier TR Mroueh KN Li F Krasich R Temm CJ Prchal JT Ingram DA Redefining endothelial progenitor cells via clonal analysis and hematopoietic stem/progenitor cell principals Blood 2007109180118091801067 10.1182/blood-2006-08-043471

23. Ingram DA, Caplice NM, Yoder MC. Unresolved questions, changing definitions, and novel paradigms for defining endothelial progenitor cells. Blood. 2005;106:1525-1531. View Article Google Scholar

24. Hill JM, Zalos G, Halcox JP, Schenke WH, Waclawiw MA, Quyyumi AA, Finkel T.

Circulating endothelial progenitor cells, vascular function, and cardiovascular risk. $\mathrm{N}$ Engl J Med. 2003;348:593-600.

View Article Google Scholar

25. Vasa M, Fichtlscherer S, Aicher A, Adler K, Urbich C, Martin H, Zeiher AM, Dimmeler S. Number and migratory activity of circulating endothelial progenitor cells inversely correlate with risk factors for coronary artery disease. Circ Res. 2001;89:e1-e7.

View Article Google Scholar

26. Lin Y Weisdorf DJ Solovey A Hebbel RP Origins of circulating endothelial cells and endothelial outgrowth from blood J Clin Invest 20001057177382587

10.1172/JCI8071

27. Hirschi KK, Ingram DA, Yoder MC. Assessing identity, phenotype, and fate of endothelial progenitor cells. Arterioscler Thromb Vasc Biol. 2008;28:1584-1595.

View Article Google Scholar

28. Handgretinger R, Gordon PR, Leimig T, Chen X, Bühring HJ, Niethammer D, Kuci S. Biology and plasticity of CD133+ hematopoietic stem cells. Ann N Y Acad Sci. 2003;996:141-151. View Article Google Scholar

29. Peichev M, Naiyer AJ, Pereira D, Zhu Z, Lane WJ, Williams M, Oz MC, Hicklin DJ, Witte L, Moore MA. Expression of VEGFR-2 and AC133 by circulating human CD34+ cells identifies a population of functional endothelial precursors. Blood. 2000;95:952-958. View Article Google Scholar

30. Case J, Mead LE, Bessler WK, Prater D, White HA, Saadatzadeh MR, Bhavsar JR, Yoder MC, Haneline LS, Ingram DA. Human CD34pAC133pVEGFR-2p cells are not endothelial progenitor cells but distinct, primitive hematopoietic progenitors. Exp Hematol. 2007;35:1109-1118. 
31. Tura O, Skinner EM, Barclay GR, Samuel K, Gallagher RC, Brittan M, Hadoke PW, Newby DE, Turner ML, Mills NL. Late outgrowth endothelial cells resemble mature endothelial cells and are not derived from bone marrow. Stem Cells. 2013;31:338-348. View Article Google Scholar

32. Sieveking DP, Buckle A, Celermajer DS, Ng MK. Strikingly Different Angiogenic Properties of Endothelial Progenitor Cell SubpopulationsInsights From a Novel Human Angiogenesis Assay. J Am Coll Cardiol. 2008;51:660-668.

View Article Google Scholar

33. Khan SS, Solomon MA, McCoy JP. Detection of circulating endothelial cells and endothelial progenitor cells by flow cytometry. Cytometry B Clin Cytom. 2005;64:1-8. View Article Google Scholar

34. Fau PJ, Seppanen E, Fau SE, Chong MSK, Chong Ms F, Yeo JSL, Yeo Js F, Teo EYL, Teo Ey F, Chan JKY, Chan Jk F, Fisk NM, Fisk Nm F, Khosrotehrani K, Khosrotehrani K. Prospective surface marker-based isolation and expansion of fetal endothelial colony-forming cells from human term placenta. Stem Cells Trans Med. 2013;2:839-847.

View Article $\underline{\text { Google Scholar }}$

35. Hofmeister C, Zhang J, Knight K, Le P, Stiff P. Ex vivo expansion of umbilical cord blood stem cells for transplantation: growing knowledge from the hematopoietic niche. Bone Marrow Transplant. 2007;39:11-23.

View Article Google Scholar

36. Corselli M, Parodi A, Mogni M, Sessarego N, Kunkl A, Dagna-Bricarelli F, Ibatici A, Pozzi S, Bacigalupo A, Frassoni F. Clinical scale ex vivo expansion of cord blood-derived outgrowth endothelial progenitor cells is associated with high incidence of karyotype aberrations. Exp Hematol. 2008;36:340-349.

View Article Google Scholar

37. Wagers AJ, Weissman IL. Plasticity of adult stem cells. Cell. 2004;116:639-648. View Article Google Scholar

38. Oswald J, Boxberger S, Jørgensen B, Feldmann S, Ehninger G, Bornhäuser M, Werner C. Mesenchymal stem cells can be differentiated into endothelial cells in vitro. Stem Cells. 2004;22:377-384.

View Article Google Scholar

39. Portalska KJ, Leferink A, Groen N, Fernandes H, Moroni L, van Blitterswijk C, de Boer J. Endothelial differentiation of mesenchymal stromal cells. PLoS One. 2012;7:e46842-. View Article Google Scholar

40. Cao Y, Sun Z, Liao L, Meng Y, Han Q, Zhao RC. Human adipose tissue-derived stem cells differentiate into endothelial cells in vitro and improve postnatal neovascularization in vivo. Biochem Biophys Res Commun. 2005;332:370-379.

View Article Google Scholar

41. Zhang Y, McNeill E, Tian H, Soker S, Andersson K-E, Yoo JJ, Atala A. Urine derived cells are a potential source for urological tissue reconstruction. J Urol. 2008;180:2226-2233. View Article Google Scholar

42. Liu G, Deng C, Zhang Y. Urine-Derived Stem Cells: Biological Characterization and Potential Clinical Applications. Stem Cells: Current Challenges and New Directions. 
2013;:19-28.

View Article Google Scholar

43. Bharadwaj S, Liu G, Shi Y, Wu R, Yang B, He T, Fan Y, Lu X, Zhou X, Liu H. Multipotential differentiation of human urine-derived stem cells: Potential for therapeutic applications in urology. Stem Cells. 2013;31:1840-1856.

View Article Google Scholar

44. Lanza R, Langer R, Vacanti JP. . Principles of Tissue Engineering. 2013;:-. View Article Google Scholar

45. Mitalipov S, Wolf D. Totipotency, pluripotency and nuclear reprogramming. Engineering of stem cells. 2009;:185-199.

View Article Google Scholar

46. Kane NM, Meloni M, Spencer HL, Craig MA, Strehl R, Milligan G, Houslay MD, Mountford JC, Emanueli C, Baker AH. Derivation of endothelial cells from human embryonic stem cells by directed differentiation analysis of microRNA and angiogenesis in vitro and in vivo. Arterioscler Thromb Vasc Biol. 2010;30:1389-1397. View Article Google Scholar

47. Levenberg S Golub JS Amit M Itskovitz-Eldor J Langer R Endothelial cells derived from human embryonic stem cells Proc Natl Acad Sci 20029943914396123658 10.1073/pnas.032074999

48. Sone M, Itoh H, Yamahara K, Yamashita JK, Yurugi-Kobayashi T, Nonoguchi A, Suzuki Y, Chao T-H, Sawada N, Fukunaga Y. Pathway for differentiation of human embryonic stem cells to vascular cell components and their potential for vascular regeneration. Arterioscler Thromb Vasc Biol. 2007;27:2127-2134.

View Article Google Scholar

49. Holland S, Lebacqz K, Zoloth L. . The human embryonic stem cell debate: science, ethics and public policy. $2001 ;:-$.

View Article Google Scholar

50. McCloskey KE, Smith DA, Jo H, Nerem RM. Embryonic stem cell-derived endothelial cells may lack complete functional maturation in vitro. J Vasc Res. 2006;43:411-421. View Article Google Scholar

51. Hentze H, Soong PL, Wang ST, Phillips BW, Putti TC, Dunn N. Teratoma formation by human embryonic stem cells: evaluation of essential parameters for future safety studies. Stem Cell Res. 2009;2:198-210.

View Article Google Scholar

52. Yildirim S. . Induced Pluripotent Stem Cells. 2012;:- .

View Article Google Scholar

53. Matsuda T Nakamura T Nakao K Arai T Katsuki M Heike T Yokota T STAT3 activation is sufficient to maintain an undifferentiated state of mouse embryonic stem cells EMBO J 199918426142691171502 10.1093/emboj/18.15.4261

54. Mitsui K, Tokuzawa Y, Itoh H, Segawa K, Murakami M, Takahashi K, Maruyama M, Maeda M, Yamanaka S. The homeoprotein Nanog is required for maintenance of pluripotency in mouse epiblast and ES cells. Cell. 2003;113:631-642. 
55. Avilion AA Nicolis SK Pevny LH Perez L Vivian N Lovell-Badge R Multipotent cell lineages in early mouse development depend on SOX2 function Genes Dev 200317 $12614019597010.1101 / \mathrm{gad} .224503$

56. Niwa H, Miyazaki J-i, Smith AG. Quantitative expression of Oct-3/4 defines differentiation, dedifferentiation or self-renewal of ES cells. Nat Genet. 2000;24:372-376. View Article Google Scholar

57. Cartwright P, McLean C, Sheppard A, Rivett D, Jones K, Dalton S. LIF/STAT3 controls ES cell self-renewal and pluripotency by a Myc-dependent mechanism. Development. 2005;132:885-896.

View Article Google Scholar

58. Jiang J, Chan Y-S, Loh Y-H, Cai J, Tong G-Q, Lim C-A, Robson P, Zhong S, Ng H-H. A core Klf circuitry regulates self-renewal of embryonic stem cells. Nat Cell Biol. 2008;10:353360.

View Article Google Scholar

59. Takahashi K, Yamanaka S. Induction of pluripotent stem cells from mouse embryonic and adult fibroblast cultures by defined factors. Cell. 2006;126:663-676.

View Article Google Scholar

60. Stadtfeld M Hochedlinger K Induced pluripotency: history, mechanisms, and applications Genes Dev 201024223922632956203 10.1101/gad.1963910

61. Choi KD Yu J Smuga-Otto K Salvagiotto G Rehrauer W Vodyanik M Thomson J Slukvin I Hematopoietic and endothelial differentiation of human induced pluripotent stem cells Stem Cells 2009275595672931800 10.1002/stem.20080922

62. Samuel R Daheron L Liao S Vardam T Kamoun WS Batista A Buecker C Schäfer R Han X Au P Generation of functionally competent and durable engineered blood vessels from human induced pluripotent stem cells Proc Natl Acad Sci 201311012774 $12779373294810.1073 /$ pnas.1310675110

63. Kim K Doi A Wen B Ng K Zhao R Cahan P Kim J Aryee M Ji H Ehrlich L Epigenetic memory in induced pluripotent stem cells Nature 20104672852903150836 10.1038/nature09342

64. S-i N, Goldstein RA, Nierras CR. The promise of human induced pluripotent stem cells for research and therapy. Nat Rev Mol Cell Biol. 2008;9:725-729.

View Article Google Scholar

65. Evensen L Micklem DR Blois A Berge SV Aarsæther N Littlewood-Evans A Wood J Lorens JB Mural cell associated VEGF is required for organotypic vessel formation PLoS One 20094 e57982688382 10.1371/journal.pone.0005798

66. Hofmann A, Ritz U, Verrier S, Eglin D, Alini M, Fuchs S, Kirkpatrick CJ, Rommens PM. The effect of human osteoblasts on proliferation and neo-vessel formation of human umbilical vein endothelial cells in a long-term 3D co-culture on polyurethane scaffolds. Biomaterials. 2008;29:4217-4226. 
67. Saito M, Hamasaki M, Shibuya M. Induction of tube formation by angiopoietin-1 in endothelial cell/fibroblast co-culture is dependent on endogenous VEGF. Cancer Sci. 2003;94:782-790.

View Article Google Scholar

68. Unger RE, Sartoris A, Peters K, Motta A, Migliaresi C, Kunkel M, Bulnheim U, Rychly J, Kirkpatrick CJ. Tissue-like self-assembly in cocultures of endothelial cells and osteoblasts and the formation of microcapillary-like structures on three-dimensional porous biomaterials. Biomaterials. 2007;28:3965-3976.

View Article Google Scholar

69. Santos MI, Unger RE, Sousa RA, Reis RL, Kirkpatrick CJ. Crosstalk between osteoblasts and endothelial cells co-cultured on a polycaprolactone-starch scaffold and the development of vascularization. Biomaterials. 2009;30:4407-4415.

View Article Google Scholar

70. Pepper MS, Montesano R, Vassalli JD, Orci L. Chondrocytes inhibit endothelial sprout formation in vitro: Evidence for involvement of a transforming growth factor-beta. $J$ Cell Physiol. 1991;146:170-179.

View Article Google Scholar

71. Tada K, Fukunaga T, Wakabayashi Y, Masumi S, Sato Y, Izumi H, Kohno K, Kumano M. Inhibition of tubular morphogenesis in human microvascular endothelial cells by coculture with chondrocytes and involvement of transforming growth factor $\beta$ : a model for avascularity in human cartilage. Biochimica et Biophysica Acta (BBA)-General Subjects. 1994;1201:135-142.

View Article Google Scholar

72. Ma DH-K, Tsai RJ-F, Chu W-K, Kao C-H, Chen J-K. Inhibition of vascular endothelial cell morphogenesis in cultures by limbal epithelial cells. Invest Ophthalmol Vis Sci. 1999;40:1822-1828.

View Article Google Scholar

73. Sherwood L, Learning C. . Human Physiology: From Cells to Systems. 2011;:-. View Article Google Scholar

74. Jain RK. Molecular regulation of vessel maturation. Nat Med. 2003;9:685-693. View Article Google Scholar

75. Davis GE, Bayless KJ, Mavila A. Molecular basis of endothelial cell morphogenesis in three-dimensional extracellular matrices. Anat Rec. 2002;268:252-275.

View Article Google Scholar

76. Place ES, Evans ND, Stevens MM. Complexity in biomaterials for tissue engineering. Nat Mater. 2009;8:457-470.

View Article Google Scholar

77. Saunders WB Bohnsack BL Faske JB Anthis NJ Bayless KJ Hirschi KK Davis GE Coregulation of vascular tube stabilization by endothelial cell TIMP-2 and pericyte TIMP-3 J Cell Biol 20061751791912064509 10.1083/jcb.200603176

78. Stratman AN Davis GE Endothelial cell-pericyte interactions stimulate basement membrane matrix assembly: influence on vascular tube remodeling, maturation, and stabilization Microsc Microanal 20121868803919655 10.1017/S1431927611012402 
79. Goerke SM, Plaha J, Hager S, Strassburg S, Torio-Padron N, Stark GB, Finkenzeller G. Human Endothelial Progenitor Cells Induce Extracellular Signal-Regulated Kinase-Dependent Differentiation of Mesenchymal Stem Cells into Smooth Muscle Cells upon Cocultivation. Tissue Eng. 2012;18:2395-2405.

View Article Google Scholar

80. Au P Tam J Fukumura D Jain RK Bone marrow-derived mesenchymal stem cells facilitate engineering of long-lasting functional vasculature Blood 20081114551 45582343592 10.1182/blood-2007-10-118273

81. Krishnan L Underwood CJ Maas S Ellis BJ Kode TC Hoying JB Weiss JA Effect of mechanical boundary conditions on orientation of angiogenic microvessels Cardiovasc Res 2008783243322840993 10.1093/cvr/cvn055

82. Stratman AN Saunders WB Sacharidou A Koh W Fisher KE Zawieja DC Davis MJ Davis GE Endothelial cell lumen and vascular guidance tunnel formation requires MT1-MMP-dependent proteolysis in 3-dimensional collagen matrices Blood 2009114 2372472714200 10.1182/blood-2008-12-196451

83. Grainger SJ Putnam AJ Assessing the permeability of engineered capillary networks in a 3D culture PLoS One 20116 e220863131402 10.1371/journal.pone.0022086

84. Sanz L, Santos-Valle P, Alonso-Camino V, Salas C, Serrano A, Vicario JL, Cuesta ÁM, Compte M, Sánchez-Martín D, Álvarez-Vallina L. Long-term imaging of human angiogenesis: Critical role of bone marrow-derived mesenchymal stem cells for the generation of durable blood vessels. Microvasc Res. 2008;75:308-314.

View Article Google Scholar

85. Holthöfer H, Virtanen I, Kariniemi A, Hormia M, Linder E, Miettinen A. Ulex europaeus I lectin as a marker for vascular endothelium in human tissues. Lab Invest. 1982;47:60-66. View Article Google Scholar

86. Vasquez SX Gao F Su F Grijalva V Pope J Martin B Stinstra J Masner M Shah N Weinstein DM Optimization of microCT imaging and blood vessel diameter quantitation of preclinical specimen vasculature with radiopaque polymer injection medium PLoS One 20116 e190993078938 10.1371/journal.pone.0019099

87. Grabherr S, Hess A, Karolczak M, Thali MJ, Friess SD, Kalender WA, Dirnhofer R, Djonov V. Angiofil@-mediated visualization of the vascular system by microcomputed tomography: A feasibility study. Microsc Res Tech. 2008;71:551-556.

View Article Google Scholar

88. Hoffman RM, Yang M. Subcellular imaging in the live mouse. Nat Protoc. 2006;1:775-782. View Article Google Scholar

89. Contag $\mathrm{CH}$, Bachmann $\mathrm{MH}$. Advances in in vivo bioluminescence imaging of gene expression. Annu Rev Biomed Eng. 2002;4:235-260.

View Article Google Scholar

90. Davis GE Stratman AN Sacharidou A Koh W Molecular basis for endothelial lumen formation and tubulogenesis during vasculogenesis and angiogenic sprouting Int Rev Cell Mol Biol 2011288 1013891664 10.1016/B978-0-12-386041-5.00003-0 
91. Lutolf M, Hubbell J. Synthetic biomaterials as instructive extracellular microenvironments for morphogenesis in tissue engineering. Nat Biotechnol. 2005;23:4755.

View Article Google Scholar

92. Sieminski A, Hebbel RP, Gooch KJ. The relative magnitudes of endothelial force generation and matrix stiffness modulate capillary morphogenesis in vitro. Exp Cell Res. 2004;297:574-584.

View Article Google Scholar

93. Stevenson M Piristine H Hogrebe N Nocera T Boehm M Reen R Koelling K Agarwal G Sarang-Sieminski A Gooch K A self-assembling peptide matrix used to control stiffness and binding site density supports the formation of microvascular networks in three dimensions Acta Biomater 20139765176614487911

10.1016/j.actbio.2013.04.002

94. Yamamura N, Sudo R, Ikeda M, Tanishita K. Effects of the mechanical properties of collagen gel on the in vitro formation of microvessel networks by endothelial cells. Tissue Eng. 2007;13:1443-1453.

View Article Google Scholar

95. Hanjaya-Putra D, Yee J, Ceci D, Truitt R, Yee D, Gerecht S. Vascular endothelial growth factor and substrate mechanics regulate in vitro tubulogenesis of endothelial progenitor cells. J Cell Mol Med. 2010;14:2436-2447.

View Article Google Scholar

96. Pandit V, Zuidema J, Venuto KN, Macione J, Dai G, Gilbert RJ, Kotha S. Evaluation of Multifunctional Polysaccharide Hydrogels with Varying Stiffness for Bone Tissue Engineering. Tissue Eng. 2013;19:2452-.

View Article Google Scholar

97. Chatterjee K Lin-Gibson S Wallace WE Parekh SH Lee YJ Cicerone MT Young MF Simon CG Jr The effect of 3D hydrogel scaffold modulus on osteoblast differentiation and mineralization revealed by combinatorial screening Biomaterials 2010315051 50623125577 10.1016/j.biomaterials.2010.03.024

98. Montaño I, Schiestl C, Schneider J, Pontiggia L, Luginbühl J, Biedermann T, BöttcherHaberzeth S, Braziulis E, Meuli M, Reichmann E. Formation of human capillaries in vitro: the engineering of prevascularized matrices. Tissue Eng Part A. 2009;16:269-282. View Article Google Scholar

99. Nichol JW Koshy ST Bae H Hwang CM Yamanlar S Khademhosseini A Cell-laden microengineered gelatin methacrylate hydrogels Biomaterials 2010315536 55442878615 10.1016/j.biomaterials.2010.03.064

100. Borenstein JT, Terai H, King KR, Weinberg E, Kaazempur-Mofrad M, Vacanti J. Microfabrication technology for vascularized tissue engineering. Biomed Microdevices. 2002;4:167-175.

View Article Google Scholar

101. Miller JS Stevens KR Yang MT Baker BM Nguyen D-HT Cohen DM Toro E Chen AA Galie PA Yu X Rapid casting of patterned vascular networks for perfusable engineered three-dimensional tissues Nat Mater 2012117687743586565 10.1038/nmat3357 
102. Crapo PM Gilbert TW Badylak SF An overview of tissue and whole organ decellularization processes Biomaterials 201132323332433084613 10.1016/j.biomaterials.2011.01.057

103. Wong ML Griffiths LG Immunogenicity in xenogeneic scaffold generation: Antigen removal versus decellularization Acta Biomater 201410180618163976714 10.1016/j.actbio.2014.01.028

104. Yang J, Yamato M, Kohno C, Nishimoto A, Sekine H, Fukai F, Okano T. Cell sheet engineering: recreating tissues without biodegradable scaffolds. Biomaterials. 2005;26:6415-6422.

View Article Google Scholar

105. Yamada N, Okano T, Sakai H, Karikusa F, Sawasaki Y, Sakurai Y. Thermo-responsive polymeric surfaces; control of attachment and detachment of cultured cells. Makromol Chem Rapid Comm. 1990;11:571-576.

View Article Google Scholar

106. Yamato M, Utsumi M, Kushida A, Konno C, Kikuchi A, Okano T. Thermo-responsive culture dishes allow the intact harvest of multilayered keratinocyte sheets without dispase by reducing temperature. Tissue Eng. 2001;7:473-480.

View Article Google Scholar

107. Shimizu T, Yamato M, Kikuchi A, Okano T. Cell sheet engineering for myocardial tissue reconstruction. Biomaterials. 2003;24:2309-2316.

View Article Google Scholar

108. Asakawa N, Shimizu T, Tsuda Y, Sekiya S, Sasagawa T, Yamato M, Fukai F, Okano T. Prevascularization of in vitro three-dimensional tissues created by cell sheet engineering. Biomaterials. 2010;31:3903-3909.

View Article Google Scholar

109. Haraguchi Y, Shimizu T, Sasagawa T, Sekine H, Sakaguchi K, Kikuchi T, Sekine W, Sekiya S, Yamato M, Umezu M. Fabrication of functional three-dimensional tissues by stacking cell sheets in vitro. Nat Protoc. 2012;7:850-858.

View Article Google Scholar

110. Unger RE, Ghanaati S, Orth C, Sartoris A, Barbeck M, Halstenberg S, Motta A, Migliaresi C, Kirkpatrick CJ. The rapid anastomosis between prevascularized networks on silk fibroin scaffolds generated in vitro with cocultures of human microvascular endothelial and osteoblast cells and the host vasculature. Biomaterials. 2010;31:6959-6967.

View Article Google Scholar

111. Xing Z, Xue Y, Finne-Wistrand A, Yang ZQ, Mustafa K. Copolymer cell/scaffold constructs for bone tissue engineering: Co-culture of low ratios of human endothelial and osteoblast-like cells in a dynamic culture system. J Biomed Mater Res. 2013;101:11131120 .

View Article Google Scholar

112. Ekaputra AK, Prestwich GD, Cool SM, Hutmacher DW. The three-dimensional vascularization of growth factor-releasing hybrid scaffold of poly $(\varepsilon-$ caprolactone)/collagen fibers and hyaluronic acid hydrogel. Biomaterials. 2011;32:81088117.

View Article Google Scholar 
113. Chen YC Lin RZ Qi H Yang Y Bae H Melero-Martin JM Khademhosseini A Functional human vascular network generated in photocrosslinkable gelatin methacrylate hydrogels Adv Funct Mater 201222202720393422083 10.1002/adfm.201101662

114. Buschmann J, Welti M, Hemmi S, Neuenschwander P, Baltes C, Giovanoli P, Rudin M, Calcagni M. Three-dimensional co-cultures of osteoblasts and endothelial cells in DegraPol foam: histological and high-field magnetic resonance imaging analyses of pre-engineered capillary networks in bone grafts. Tissue Eng. 2010;17:291-299. View Article Google Scholar

115. Quent V Loessner D Friis T Reichert JC Hutmacher DW Discrepancies between metabolic activity and DNA content as tool to assess cell proliferation in cancer research J Cell Mol Med 2010141003 10133823131 10.1111/j.15824934.2010.01013.x

116. Zhang Y, Schedle A, Matejka M, Rausch-Fan X, Andrukhov O. The proliferation and differentiation of osteoblasts in co-culture with human umbilical vein endothelial cells: an improved analysis using fluorescence-activated cell sorting. Cell Mol Biol Lett. 2010;15:517-529.

View Article Google Scholar

117. Maciag T Cerundolo J Ilsley S Kelley P Forand R An endothelial cell growth factor from bovine hypothalamus: identification and partial characterization Proc Natl Acad Sci 19797656745678411712 10.1073/pnas.76.11.5674

118. Terramani TT, Eton D, Bui PA, Wang Y, Weaver FA, Yu H. Human macrovascular endothelial cells: optimization of culture conditions. In Vitro Cell Dev Biol-Anim. 2000;36:125-132.

View Article Google Scholar

119. Bartoli M, PLATT D, Lemtalsi T, Gu X, Brooks SE, Marrero MB, Caldwell RB. VEGF differentially activates STAT3 in microvascular endothelial cells. FASEB J. 2003;17:1562-1564.

View Article Google Scholar

120. Craig LE, Spelman JP, Strandberg JD, Zink MC. Endothelial cells from diverse tissues exhibit differences in growth and morphology. Microvasc Res. 1998;55:65-76.

View Article Google Scholar

121. Mirshahi F, Pourtau J, Li H, Muraine M, Trochon V, Legrand E, Vannier J-P, Soria J, Vasse M, Soria C. SDF-1 activity on microvascular endothelial cells: consequences on angiogenesis in in vitro and in vivo models. Thromb Res. 2000;99:587-594.

View Article Google Scholar

122. Lang I, Pabst MA, Hiden U, Blaschitz A, Dohr G, Hahn T, Desoye G. Heterogeneity of microvascular endothelial cells isolated from human term placenta and macrovascular umbilical vein endothelial cells. Eur J Cell Biol. 2003;82:163-173.

View Article Google Scholar

123. Mannello F, Tonti GA. Concise Review: No Breakthroughs for Human Mesenchymal and Embryonic Stem Cell Culture: Conditioned Medium, Feeder Layer, or Feeder-Free; Medium with Fetal Calf Serum, Human Serum, or Enriched Plasma; Serum-Free, Serum Replacement Nonconditioned Medium, or Ad Hoc Formula? All That Glitters Is Not Gold!. Stem Cells. 2007;25:1603-1609. 
124. Gstraunthaler G. Alternatives to the use of fetal bovine serum: serum-free cell culture. Altex. 2003;20:275-281.

View Article Google Scholar

125. Kuznetsov SA, Mankani MH, Robey PG. Effect of serum on human bone marrow stromal cells: ex vivo expansion and in vivo bone formation. Transplantation. 2000;70:1780-1787. View Article Google Scholar

126. Zeisberger SM, Zoller S, Riegel M, Chen S, Krenning G, Harmsen MC, Sachinidis A, Zisch AH. Optimization of the culturing conditions of human umbilical cord bloodderived endothelial colony-forming cells under xeno-free conditions applying a transcriptomic approach. Genes Cells. 2010;15:671-687.

View Article Google Scholar

127. Huang L Critser PJ Grimes BR Yoder MC Human umbilical cord blood plasma can replace fetal bovine serum for in vitro expansion of functional human endothelial colony-forming cells Cytotherapy 2011137127213387926

$10.3109 / 14653249.2010 .548380$

128. Harvey K, Siddiqui RA, Sliva D, Garcia JG, English D. Serum factors involved in human microvascular endothelial cell morphogenesis. J Lab Clin Med. 2002;140:188-198. View Article Google Scholar

129. Reinisch A Hofmann NA Obenauf AC Kashofer K Rohde E Schallmoser K Flicker K Lanzer G Linkesch W Speicher MR Humanized large-scale expanded endothelial colony-forming cells function in vitro and in vivo Blood 2009113671667252710924 10.1182/blood-2008-09-181362

130. Denecke B, Horsch LD, Radtke S, Fischer JC, Horn PA, Giebel B. Human endothelial colony-forming cells expanded with an improved protocol are a useful endothelial cell source for scaffold-based tissue engineering. J Tissue Eng Regen Med. 2013;:- .

View Article Google Scholar

131. Iyer RK, Chiu LL, Radisic M. Microfabricated poly (ethylene glycol) templates enable rapid screening of triculture conditions for cardiac tissue engineering. J Biomed Mater Res. 2009;89:616-631.

View Article Google Scholar

132. Iyer RK Chiu LL Vunjak-Novakovic G Radisic M Biofabrication enables efficient interrogation and optimization of sequential culture of endothelial cells, fibroblasts and cardiomyocytes for formation of vascular cords in cardiac tissue engineering Biofabrication 201240350024482345 10.1088/1758-5082/4/3/035002

133. Lovett M, Lee K, Edwards A, Kaplan DL. Vascularization strategies for tissue engineering. Tissue Eng. 2009;15:353-370.

View Article Google Scholar

134. Tufro-McReddie A, Norwood V, Aylor K, Botkin S, Carey R, Gomez R. Oxygen regulates vascular endothelial growth factor-mediated vasculogenesis and tubulogenesis. Dev Biol. 1997;183:139-149. 
135. Rey S Semenza GL Hypoxia-inducible factor-1-dependent mechanisms of vascularization and vascular remodelling Cardiovasc Res 2010862362422856192 $10.1093 / \mathrm{cvr} / \mathrm{cvq} 045$

136. Shweiki D, Itin A, Soffer D, Keshet E. Vascular endothelial growth factor induced by hypoxia may mediate hypoxia-initiated angiogenesis. Nature. 1992;359:843-845. View Article Google Scholar

137. Liu K, Chi L, Guo L, Liu X, Luo C, Zhang S, He G. The interactions between brain microvascular endothelial cells and mesenchymal stem cells under hypoxic conditions. Microvasc Res. 2008;75:59-67.

View Article Google Scholar

138. Kanichai M, Ferguson D, Prendergast PJ, Campbell VA. Hypoxia promotes chondrogenesis in rat mesenchymal stem cells: A role for AKT and hypoxia-inducible factor (HIF)-1 $\alpha$. J Cell Physiol. 2008;216:708-715.

View Article Google Scholar

139. Xu N, Liu H, Qu F, Fan J, Mao K, Yin Y, Liu J, Geng Z, Wang Y. Hypoxia inhibits the differentiation of mesenchymal stem cells into osteoblasts by activation of Notch signaling. Exp Mol Pathol. 2012;9:33-39.

View Article Google Scholar

140. Xing Z, Xue Y, Dånmark S, Schander K, Østvold S, Arvidson K, Hellem S, Finne-Wistrand A, Albertsson AC, Mustafa K. Effect of endothelial cells on bone regeneration using poly (Llactide-co-1, 5-dioxepan-2-one) scaffolds. J Biomed Mater Res. 2011;96:349-357.

View Article Google Scholar

141. Liu Y, Teoh S-H, Chong MS, Yeow C-H, Kamm RD, Choolani M, Chan JK. Contrasting Effects of Vasculogenic Induction Upon Biaxial Bioreactor Stimulation of Mesenchymal Stem Cells and Endothelial Progenitor Cells Cocultures in ThreeDimensional Scaffolds Under In Vitro and In Vivo Paradigms for Vascularized Bone Tissue Engineering. Tissue Eng. 2012;19:893-904.

View Article Google Scholar

142. Campbell GR, Campbell JH. Development of tissue engineered vascular grafts. Curr Pharm Biotechnol. 2007;8:43-50.

View Article Google Scholar

143. Ferrara N, Gerber HP. Vascular endothelial growth factor molecular and biological aspects. Advances Organ Biol. 1999;7:25-57.

View Article Google Scholar

144. Sorrell JM Baber MA Caplan AI Influence of adult mesenchymal stem cells on in vitro vascular formation Tissue Eng Part A 200915175117612792097

10.1089/ten.tea.2008.0254

145. Bronckaers A, Hilkens P, Martens W, Gervois P, Ratajczak J, Struys T, Lambrichts I.

Mesenchymal stem/stromal cells as a pharmacological and therapeutic approach to accelerate angiogenesis. Pharmacol Ther. 2014;143:181-196.

View Article Google Scholar

146. Chintalgattu V, Nair DM, Katwa LC. Cardiac myofibroblasts: a novel source of vascular endothelial growth factor (VEGF) and its receptors Flt-1 and KDR. J Mol Cell Cardiol. 
147. Carmeliet P Jain RK Molecular mechanisms and clinical applications of angiogenesis Nature 20114732983074049445 10.1038/nature10144

148. Suri C, Jones PF, Patan S, Bartunkova S, Maisonpierre PC, Davis S, Sato TN, Yancopoulos GD. Requisite role of angiopoietin-1, a ligand for the TIE2 receptor, during embryonic angiogenesis. Cell. 1996;87:1171-1180.

View Article Google Scholar

149. Koblizek TI, Weiss C, Yancopoulos GD, Deutsch U, Risau W. Angiopoietin-1 induces sprouting angiogenesis in vitro. Current Biol. 1998;8:529-532.

View Article Google Scholar

150. Salcedo R, Oppenheim JJ. Role of chemokines in angiogenesis: CXCL12/SDF-1 and CXCR4 interaction, a key regulator of endothelial cell responses. Microcirculation. 2003; 10:359-370.

View Article Google Scholar

151. Sato N Beitz J Kato J Yamamoto M Clark J Calabresi P Raymond A Frackelton A Jr Platelet-derived growth factor indirectly stimulates angiogenesis in vitro Am J Pathol 199314211191886859

152. Hellberg C, Ostman A, Heldin C-H. PDGF and vessel maturation. Angiogenesis inhibition. 2010;:103-114.

View Article Google Scholar

153. Gaengel K, Genové G, Armulik A, Betsholtz C. Endothelial-mural cell signaling in vascular development and angiogenesis. Arterioscler Thromb Vasc Biol. 2009;29:630-638.

View Article Google Scholar 